\title{
The Purpose of the Use Classroom Language
}

\section{I.A.P.P.H. Oka ${ }^{1 *}$, L.P. Artini' ${ }^{2}$ D 1,2,3 English Language Education, Ganesha University of Education, Singaraja, Indonesia}

\section{A R T I C L E I N F O}

Article history:

Received September 09, 2021

Revised September 12, 2021

Accepted November 17, 2021

Available online December 25, 2021

Kata Kunci:

Bahasa Kelas, Tujuan, Memotivasi,

Menginstruksikan, Membimbing

Keywords:

Classroom Language, Purpose,

Motivate, Instruct, Guide

DOI:

http://dx.doi.org/10.23887/jpbi.v9i3.43 105

\section{A B S T R A C T}

\begin{abstract}
A B S T RA K
Saat ini masih banyak yang tidak bisa menggunakan bahasa Inggris. Hasil penelitian sebelumnya juga menyatakan bahwa penyebab siswa tidak bisa berbahasa Inggris karena siswa menganggap belajar bahasa Inggris itu rumit. Bahasa Inggris dalam kehidupan sehari-hari masih jarang, sehingga siswa kesulitan memahami bahasa Inggris. Penelitian ini bertujuan untuk menganalisis bahasa kelas yang digunakan oleh guru bahasa Inggris dan untuk menganalisis tujuan penggunaan bahasa kelas selama proses pembelajaran. Penelitian ini menggunakan studi kasus dengan menggunakan penelitian kualitatif deskriptif. Objek penelitian ini adalah 1 orang guru bahasa Inggris. Pengumpulan data dilakukan dengan observasi dan wawancara. Teknik analisis data yang digunakan adalah deskriptif kualitatif dan analisis kuantitatif. Hasil penelitian ini menunjukkan bahwa pertama, guru bahasa Inggris menggunakan bahasa berdasarkan situasi yang dihadapi selama kelas. Kedua, guru memilih bahasa kelas berdasarkan tujuan guru dari siswa selama proses pembelajaran. Studi ini mengkategorikan tiga tujuan penggunaan bahasa kelas: memotivasi, menginstruksikan, dan membimbing. Setiap rencana memiliki frekuensi yang berbeda dalam satu kali pertemuan. Hasil analisis tersebut didukung oleh pernyataan guru yang diperoleh melalui wawancara mengenai bagaimana situasi memerlukan jenis tujuan bahasa tertentu. Penggunaan bahasa kelas memiliki tujuan yang berbedabedasesuai dengan situasi saat ini dalam jangkauan pembelajaran.
\end{abstract}

Currently, there are still many who cannot use English. The results of previous studies also stated that the cause of students not being able to speak English was because students thought learning English was complicated. English in everyday life is still rare, so students have difficulty understanding English. This study aimed to analyze the classroom language used by the English teacher and to analyze the purpose of using the classroom language during the learning process. This study uses a case study using descriptive qualitative research. The object of this research is 1 English teacher. Data were collected by observation and interviews. The technique used to analyze the data is descriptive qualitative and quantitative analysis. The results of this study indicate that first, the English teacher uses language based on the situations encountered during class. Second, the teacher chooses the class language based on the teacher's goals from the students during the learning process. This study categorizes three purposes of classroom language use: motivating, instructing, and guiding. Each plan has a different frequency in one meeting. The analysis results are supported by the teacher's statements obtained through interviews regarding how the situation requires certain types of language objectives. The use of classroom language has different purposes according to the current situation in the learning range.

This is an open-access article under the CC BY-SA license. Copyright (C) 2021 by Author. Published by Universitas Pendidikan Ganesha.

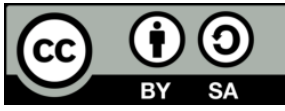

\section{INTRODUCTION}

English currently occupies the greatest place as a global language in communicating between people who come from different mother tongues. English, which is known as an international language, is based on the population of countries whose official language or second language is English (Selvi et al., 2020; Tanihardjo, 2016; Thoyyibah et al., 2019; Yunita \& Maisarah, 2020). There are 67 countries that use English as an official language, and 27 other countries declared English as a second language (Butova et al., 2019; Nishanthi, 2018). Out of those countries, several countries also consider English as an international foreign language, as evidenced by the additional English subject in schools (Liu \& Song, 2021; Majid et al., 2012; Mohammadi et al., 2020). Its existence as a foreign language in Indonesia is intended to open the way to compete globally with other countries in terms of economy, tourism, technology, education, etc. As a foreign language that must be obtained separately from the mother language of students (Mahmoudi et al., 2012; Masrur et al., 2020; Sulistiyo, 2018). Mastery of a foreign language demands persistence of training and patience among students and teachers. Therefore, the presence of a teacher is very important for the progress of students in gaining the language (Khotimah et al., 2019; Sert \& Boynueğri, 2017).

However, today's problem is that there are still many who cannot use English. Based on the results of previous studies, it was also stated that the cause of students not being able to speak English was because students 
considered learning English complicated (Annisa et al., 2018a; Liyana \& Kurniawan, 2019; Wahyudin et al., 2020; Yusnidar, 2014). In addition, the use of English in everyday life is infrequent, so students have difficulty learning English (Annisa et al., 2018b; Dwihartanti \& Faizah, 2018; Hamidah \& Yanuarmawan, 2018). Based on those enlightenments of how English has become important, in Indonesia itself, English language teaching might be acquired either through courses or international or private schools. Furthermore, in Indonesia, English is the subject of choice for students at the elementary school, on the other hand, it has been a compulsory subject that must be taken for junior high school students (Alwasilah, 2013; Ratminingsih, 2017; Sya \& Helmanto, 2020). Since students entered junior high school, they will be obliged to learn English as a foreign language. At junior high school, the level of the way students think will be developing differently. For some students who are already familiar with English in elementary school, they tend to only know the vocabulary they encounter daily (Century et al., 2020; Megawati \& Utami, 2020). While in junior high school, students should be directed to start communicating with their teachers or friends. Besides remembering the vocabulary choices, practicing English to become fluent requires consistent practice through simple conversations both outside and inside the classroom (Hanifa, 2018; Mauliate et al., 2019; Tseng, 2014). These conversations can be categorized as classroom language used between students to teacher and vice versa teacher to students in the appropriate template.

The use of classroom language in junior high school and elementary school students tends to face particular issues (Hanifa, 2018; Megawati \& Utami, 2020). Junior high school students are considered to be able to analyze and even use what teacher say in daily conversations, but in elementary school, teacher only needs the responses of the students by using certain classroom language. Indirectly the use of classroom language encourages students to be confident in using a language that is not a native language (Areni, 2010; Hamidah \& Yanuarmawan, 2018; Liyana \& Kurniawan, 2019). In this regard, building students' fluency can be achieved by getting them used to respond continuously to the classroom language uttered by the teacher. Classroom language is the right way to solve problems necessarily as a solution to the problems faced by students, as well as increasing the confidence of the teacher himself. The flexibility of teachers in using classroom language reflects how confident they are to teach students and provide a positive atmosphere (Annisa et al., 2018b; Dwihartanti \& Faizah, 2018; Lubis, 2018).

On the other hand, the use of classroom language is likely to be a fairly active and effective strategy in motivating based on the abilities of each student (Rokhman \& Yuliati, 2010; Widyahening, 2018). Its use of classroom language by the teacher is precise essential in the teaching and learning process, they are used to communicate and interact verbally and in writing in English (Albaladejo et al., 2018; Parvareshbar \& Ghoorchaei, 2016; Zarei \& Afshar, 2014). Classroom language in general can be said as expressions used in interacting in the classroom between teachers and students (Leona et al., 2021; Martriwati et al., 2018). Such opportunities tend to require or begin with teacher-to-student, which will lead to student-to-teacher to give feedback in interacting with English in the classroom. It emphasizes that the use of classroom language focuses on helping students to express broadly in their interactions, in this case in English. The purpose of classroom language in this case is English to help students fully catch the meaning of the language and relate it to real communication (Bella \& Zainil, 2020; Hadiatmi et al., 2020). If the teacher gives instructions using the classroom language, students will be more familiar with these expressions in general and after that, they will use them slowly with a little practice (Hadiatmi et al., 2020; Thoyyibah et al., 2019). In other words, the purpose of using classroom language is to familiarize students with phrases that can be used later. There are other specific purposes of using classroom language, as follows: First, to motivate. Classroom language has a purpose to motivate students to be more active during English lessons (Whitehead, 2021; Yang et al., 2022). By giving an inducement in the form of classroom language, indirectly students will get new vocabulary every time. In addition, students also learn how the vocabulary is used in a sentence, even on other occasions they can hear directly how it is pronounced from their teacher (Habibi, 2017; Parvareshbar \& Ghoorchaei, 2016; Zarei \& Afshar, 2014). These exercises can indirectly build students' desire to learn without feeling pressured and worried.

Second, to instruct. An instruction is usually used in addition to familiarizing students with input in the form of a targeted language, in this case, English, as well as being used as a communication medium to organize the classroom (Alshenqeeti, 2018; Sari, 2016; Yafaei \& Attamimi, 2019). Third, to guide. In a progress to improve students' language skills, inevitably demands the teacher's efforts to include languages that are easily understood by students in the learning process. These languages are one of the purposes of the beneficial classroom language for teachers, which is known as guidance. The classroom language indirectly gives the teacher a duty to guide students in using English naturally (Sujarwo, 2020; Wichadee, 2011; Widyahening, 2018). This guidance will make it easier for students to master a language rendering to a certain context, and use the language based on the imposed feelings. Using classroom language, students are expected to be more accustomed to formulating what they want to say (Areni, 2010; Sadegi, 2019). In addition, students are also expected to be able to build selfconfidence in the use of their target language, which is English. Therefore, based on the above phenomena, the authors were interested in conducting more in-depth research on classroom language. This study aimed to analyze how the classroom language is used by English teachers and analyze the purpose of using classroom language during the learning process 


\section{METHOD}

This research was conducted to identify the purpose of using classroom language by teachers at SMP Negeri 2 Amlapura during online learning. This research was designed by the researcher with a case study using descriptive qualitative research. Since the study was conducted as a case study, the chosen subject was only one EFL teacher. This one EFL was representative of how data would be generated and identified in depth. One of the public schools in Karangasem Regency was the chosen place where this research was conducted. Specifically, the teacher as the main participant teaches the eighth-grade students in SMP N 2 Amlapura. From eleven classes, the data was obtained from two classes of eighth grade. In the study that was conducted by the researcher, based on the considerations, it was determined that two of the instruments were used to collect the data. The two instruments were observation and interview. Data collection by observation and interviews resulted in abundant data sources from the observation checklist and teacher interview answers. The data sources collected from the observation and interview were analyzed by using three steps of data analysis, including data reduction, data display, and data verification.

\section{RESULT AND DISCUSSION}

\section{Result}

SMP N 2 Amlapura is one of junior high school in Karangasem Regency. The chosen subject was based on the research design that uses a case study. In this case study, the subject was considered as the representation and had studied deeply. This research finding presented the use of classroom language by the teacher. Additionally, the discussion presented the purpose of the use of the classroom language from the teacher's interview. This study aimed to find out how the teacher uses classroom language with each purpose. The researcher found that there were three types of goals in the use of classroom language in the classroom by the teacher in the class being studied. The three purposes of using classroom language were to motivate, instruct, and guide students. In this regard, from the results of observations and interviews, the use of classroom language related to the three objectives above was carried out and selected for each consideration. The decision was taken from the current class situation. The teacher also stated that the classroom language bridges the communication between teachers and students.

The data collection was done in 3 meetings. The three meetings were carried out online through the WhatsApp group. In this group, the teacher began the lesson which briefly included the objectives and the material to be studied by the students. Most of the observation period found that the use of classroom language led to daily language in the classroom. The identified classroom language reflected the teacher's efforts to communicate with students. Based on the classroom language utterances, students responded and provided feedback through conversations in the group. Based on data analysis found that the highest percentage of the use of classroom language was to instruct purpose as much as $49.12 \%$, then followed by the number of to guide purpose which was $33.33 \%$, and the remaining $17.54 \%$ to motivate purpose. The emergence of these numbers was calculated from the total number of sentences in 3 meetings at once for 1 purpose. First, the purpose to motivate was found 10 identified sentences used by the teacher during teaching. Second, 28 sentences were identified included the purpose to instruct. Last, the purpose to guide was found as many as 15 sentences that were identified. The use of these sentences was sometimes repeated or had almost the same meaning even though the wording was not the same.

Examples of sentences that are often used by teachers in 3 observation meetings are as follows. First, classroom language to motivate students. As stated in the table above, in the first meeting there were 3 sentences, in the second meeting there were 2 sentences, and in the third meeting, there were 5 sentences that indicated that they could be classified into the purpose of the classroom language to motivate. Most of these sentences had the same meaning and were used in almost the same situations. Situations that often gave a rise to this purpose were when students provided feedback on questions or when the teacher expected students to respond. Therefore indirectly, by being motivated students were interested and wanted to participate more. The following are sentences that often appeared during the learning process: "Okay good job, thank you so much". The sentence above was said by the teacher when students responded as expected by the teacher. Students completed the attendance checks properly and regularly through the group. The student's efforts support teachers to use classroom language to motivate them by giving verbal rewards. The provision of classroom language had the same purpose as reinforcing to motivate students. Therefore, other students followed their friends to do the same way.

"You are lucky enough to study English today". The sentence above was categorized into using classroom language to motivate. The teacher explained that the opportunity to conduct discussion through Whatsapp group, which was not always possible; therefore, the meeting became a valuable opportunity for students. Therefore, it was expected that students can attend class well and participate fully. "You will get 10 bonus points". The last classroom language was in the form of reinforcement as well. The use of classroom language occurred when the teacher gave questions to students and offered 10 bonus points for students who can answer questions correctly. Giving bonus points motivated students to be more active and contribute during the learning process. It was also 
supported through interviews conducted with the teacher; the use of classroom language to motivate was based on the teacher's efforts to arouse students' enthusiasm for learning. Classroom language served to make students more active and challenged to use English. Focusing on the goal of increasing student motivation in learning, indirectly the classroom language used by teachers also encouraged students to be more competitive. During the observation period, it was found that the characteristics of the classroom language used by the teacher to motivate contained elements of verbal or spoken reinforcement.

\section{Discussion}

First, Classroom language to instruct the student. Reflecting on the results of the observations, the purpose to instruct was to have the highest number of classroom language usages. Instructions have the most important role in managing the class and managing the students themselves (Sadegi, 2019; Sert \& Boynueğri, 2017; SiebererNagler, 2015). Below are some sentences that were included the purpose of classroom language used by the teacher during the observation period, as follows: "Please, read the rules!". This classroom language was used by the teacher before learning begins. At first, the teacher asked them to read the meeting rules that had been shared through the Whatsapp group. Students had an idea of how the meeting will go and paid close attention. Asking students to read the rules was a classroom language that was instructing so that the class can be well organized. "Please, stay on this group for 90 minutes!. The sentence above was an example of another classroom language found by the researcher during the observation period. This situation occurred when the teacher starts the class. She asked students to stay in the discussion. This instruction was addressed to all students. The effort to organize was the purpose of using classroom language to instruct the class by the teacher (Aguirre et al., 2016; Gozcu \& Caganaga, 2016; Raynesa, 2019). When students participated well, the teacher could see the students' contribution and give a score for each student. "Click the link below!". Another classroom language used by the teacher was the sentence above. This sentence was in the form of instruction used by the teacher when the teacher was explaining the material and asking the student to click a link that contained the material. Therefore, the teacher instructed students with the classroom language above to give orders for these students to have the same material sources.

Additionally, during observations and interviews that had been conducted, the use of classroom language to instruct was also based on several considerations of the classroom situation being faced by the teacher. Because learning was held online, all forms of instructions given by the teacher were technological (Arnó-Macià \& RuedaRamos, 2011; Huang, 2020; Liu \& Song, 2021). Instructions also became stricter due to the distance between teachers and students who were not in the same place. The use of classroom language certainly supported the teacher to keep managing the class and controlling student activities outside of the learning context at that time (Nartiningrum \& Nugroho, 2020; Putra, 2021; Rinekso \& Muslim, 2020). By using this instructional classroom language, indirectly invited students to respond to the teacher (Fitria, 2020; Meşe \& Sevilen, 2021; Sujarwo et al., 2020). This response can be considered as reciprocal communication between the students and the teacher.

Second, Classroom language to guide the student. The last finding which was categorized as one of the purposes of the classroom language used by the teacher is to guide. This purpose occupied the second position with the highest number of uses during the lesson. The use of this classroom language was to guide students during the learning process (Cekaite, 2017; Moghadam et al., 2021; York, 2011). From the results of observations, there were 3 examples of classroom language that can be categorized into classroom language which aimed to guide the students. The following was a description of the situation used in the three sentences below: "If you want to ask something, you can tag my name, then type "I want to ask Miss". The example sentence above was often used by teachers in almost all meetings. The use of the classroom language was related to the "to guide" purpose where the teacher guided students to do something. This form of classroom language made it easier for the teacher to control students and made it easier for students to participate (Alshenqeeti, 2014; Sert \& Boynueğri, 2017; Sujarwo, 2020). Due to the limitations of communication through the WhatsApp group, it sometimes caused the teacher to break in response to students. Hence the classroom language was used to guide students to have more opportunities to interact with the teacher (Sieberer-Nagler, 2015; Szöcs, 2017). "First, find something that make you smile this morning". The use of sentences from the classroom language above was usually found when the class has started. In this case, the situation of using sentences spoken by the teacher was when the teacher gave apperception in the form of a simple small game. This classroom language was precisely suitable in its use for this purpose (Tovar Viera et al., 2020; Wilt et al., 2021). "Now I would like you to show me a thing in your house that has green in color". The next activity was the teacher used the sentence above to guide the students. The use of the classroom language was still in the situation of game activities in apperception (Kamelia, 2019; Saito et al., 2018; Tuzlukova et al., 2017). The teacher-guided students to show items around them that were green. Therefore, students knew what the teacher wanted and followed the guidance given by the teacher. Further, the last use of classroom language was to guide students. As with other purposes, the use of classroom language was also based on situations that occur in class. Due to online learning, the teacher was not able to guide students with body language or other languages; therefore a big role for written classroom language was needed (Haselow, 2021; Sari, 
2016; Singh et al., 2020). The teacher also stated that providing a guide in the form of classroom language, helped students to understand what they should do. In general, with this classroom language, the teacher allows students to process what the teacher says during the learning process.

\section{CONCLUSION}

The use of classroom language has different purposes according to the current situation in the period of the lesson. Since this research focuses on several purposes of using the classroom language itself, the data analyzed is also based on the facts found in the field when the teacher teaches. Those purposes are to motivate, instruct, and guide. Overall, it can be concluded that at a certain point in the situation, teachers can use a variety of classroom language. Classroom language variations also help teachers communicate their hopes and desires and help students understand the intent and purpose of what the teacher is saying. In addition, the situation and student responses also play an important role in the choice of classroom language and decisions on spoken or written classroom language with each required purpose.

\section{REFERENCES}

Aguirre, D., Bustinza, D., \& Garvich, M. (2016). Influence of Songs in Primary School Students' Motivation for Learning English in Lima, Peru. English Language Teaching, 9(2), 178. https://doi.org/10.5539/elt.v9n2p178.

Albaladejo, S. A., Coyle, Y., \& Larios, J. R. de. (2018). Songs, stories, and vocabulary acquisition in preschool learners of English as a foreign language. System, 76. https://doi.org/10.1016/j.system.2018.05.002.

Alshenqeeti, H. (2014). Interviewing as a Data Collection Method: A Critical Review. English Linguistics Research, 3(1), 39-45. https://doi.org/10.5430/elr.v3n1p39.

Alshenqeeti, H. (2018). Motivation and Foreign Language Learning: Exploring the Rise of Motivation Strategies in the EFL Classroom. International Journal of Applied Linguistics and English Literature, 7(7), 1. https://doi.org/10.7575/aiac.ijalel.v.7n.7p.1.

Alwasilah, A. C. (2013). Policy on Foreign Language Education in Indonesia. International Journal of Education, 7(1), 1-19. https://doi.org/10.17509/ije.v7i1.5302.

Annisa, N., Saragih, A. H., \& Mursid. (2018a). Pengembangan Media Pembelajaran Interaktif Pada Mata Pelajaran Bahasa Inggris. Jurnal Teknologi Informasi Dan Komunikasi Dalam Pendidikan, 5(2). https://doi.org/10.24114/jtikp.v5i2.12599.

Annisa, N., Saragih, A. H., \& Mursid, R. (2018b). Pengembangan Media Pembelajaran Interaktif Pada Mata Pelajaran Bahasa Inggris. Jurnal Teknologi Informasi Dan Komunikasi Dalam Pendidikan, 5(2). https://doi.org/10.24114/jtikp.v5i2.12599.

Areni, G. K. D. (2010). Optimizing the Use of Classroom Language To Improve the Speaking Confidence of Students at Beginner Level. Language Circle: Journal of Language and Literature, 5(1), 1-8. https://doi.org/10.15294/lc.v5i1.1986.

Arnó-Macià, E., \& Rueda-Ramos, C. (2011). Promoting reflection on science, technology, and society among engineering students through an EAP online learning environment. Journal of English for Academic Purposes, 10(1). https://doi.org/10.1016/j.jeap.2010.12.004.

Bella, M. S., \& Zainil, Y. (2020). An Analysis of Teachers' classroom Language at SMPN 4 Muara Bungo. Journal of English Language Teaching, 9(4), 644-651. https://doi.org/10.24036/jelt.v9i4.110200.

Butova, Dubskikh, A., Kisel, O. V., \& Chigintseva, E. (2019). Electronic educational environment Moodle in English language training. Arab World English Journal (AWEJ), 10. https://doi.org/10.24093/awej/vol10no1.4.

Cekaite, A. (2017). What Makes a Child a Good Language Learner? Interactional Competence, Identity, and Immersion in a Swedish Classroom. Annual Review of Applied Linguistics, 37, 45-61. https://doi.org/10.1017/S0267190517000046.

Century, J., Ferris, K. A., \& Zuo, H. (2020). Finding time for computer science in the elementary school day: a quasi-experimental study of a transdisciplinary problem-based learning approach. International Journal of STEM Education, 7(1). https://doi.org/10.1186/s40594-020-00218-3.

Dwihartanti, M., \& Faizah, N. N. (2018). Pentingnya Penguasaan Bahasa Inggris Bagi Pelaksanaan Tugas Rutin Sekretaris. Efisiensi - Kajian Ilmu Administrasi, 15(1). https://doi.org/10.21831/efisiensi.v15i1.24483.

Fitria, T. N. (2020). Teaching English through Online Learning System during Covid-19 Pandemic. Pedagogy: Journal of English Language Teaching, 8(2), 138-148. https://doi.org/10.32332/pedagogy.v8i2.

Gozcu, E., \& Caganaga, C. K. (2016). The importance of using games in EFL classrooms. Cypriot Journal of Educational Sciences, 11(3), 126. https://doi.org/10.18844/cjes.v11i3.625. 
Habibi, N. (2017). The Use of Flashcards in Improving Vocabulary Mastery of Students with Disability. Inklusi Journal Of Disability Studies, 121. https://doi.org/10.14421/ijds.040203.

Hadiatmi, I. N., Wilian, S., \& Yusra, K. (2020). Classroom Languages As Used By English Teachers At Indonesian Junior High Schools In Smpn 1 Keruak. Jurnal Ilmiah Pendidikan Indonesia, 2(1), 81-89.

Hamidah, F. N., \& Yanuarmawan, D. (2018). Pemanfaatan Internet Untuk Memvariasikan Sumber Belajar Bahasa Inggris dalam Meningkatkan Kinerja Guru. Jurnal ABDINUS : Jurnal Pengabdian Nusantara, 2(1). https://doi.org/10.29407/ja.v2i1.11790.

Hanifa, R. (2018). EFL Published Materials: An Evaluation of English Textbooks for Junior High School in Indonesia. Advances in Language and Literary Studies, 9(2), 166. https://doi.org/10.7575/aiac.alls.v.9n.2p.166.

Haselow, A. (2021). The acquisition of pragmatic markers in the foreign language classroom: An experimental study on the effects of implicit and explicit learning. Journal of Pragmatics, 186. https://doi.org/10.1016/j.pragma.2021.09.017.

Huang, Y. (2020). Research on Online Education in the Midst of the COVID-19 Pandemic. Journal of Advances in Education Research, 5(2), 125-137. https://doi.org/10.22606/jaer.2020.52005.

Kamelia, K. (2019). Using Video as Media of Teaching in English Language Classroom: Expressing Congratulation and Hopes. Utamax : Journal of Ultimate Research and Trends in Education, 1(1), 3438. https://doi.org/10.31849/utamax.v1i1.2742.

Khotimah, K., Widiati, U., Mustofa, M., \& Faruq Ubaidillah, M. (2019). Autonomous English learning: Teachers’ and students' perceptions. Indonesian Journal of Applied Linguistics, 9(2), 371-381. https://doi.org/10.17509/ijal.v9i2.20234.

Leona, N. L., Koert, M. J. H. van, Molen, M. W. van der, Rispens, J. E., Tijms, J., \& Snellings, P. (2021). Explaining individual differences in young English language learners' vocabulary knowledge: The role of Extramural English Exposure and motivation. System, 96. https://doi.org/10.1016/j.system.2020.102402.

Liu, H., \& Song, X. (2021). Exploring “Flow" in young Chinese EFL learners' online English learning activities. System, 91. https://doi.org/10.1016/j.system.2020.102425.

Liyana, A., \& Kurniawan, M. (2019). Speaking Pyramid sebagai Media Pembelajaran Kosa Kata Bahasa Inggris Anak Usia 5-6 Tahun. Jurnal Obsesi: Journal of Early Childhood Education, 3(1). https://doi.org/10.31004/obsesi.v3i1.178.

Lubis, A. (2018). Integrasi Tik Dalam Pengajaran Bahasa Inggris Di Indonesia Abad Ke-21: Mitos Dan Realita. Cakrawala Pendidikan, 37(1), 11-24. https://doi.org/10.21831/cp.v37i1.16738.

Mahmoudi, E., Samad, A. bt A., \& Razak, N. Z. B. A. (2012). Attitude and Students' Performance in Computer Assisted English Language Learning (CAELL) for Learning Vocabulary. Procedia - Social and Behavioral Sciences, 66. https://doi.org/10.1016/j.sbspro.2012.11.293.

Majid, M. S. Z. B. A., Ali, M. M. B. A., Rahim, A. A. B. A., \& Khamis, N. Y. B. (2012). The Development of Technical English Multimedia Interactive Module to Enhance Student Centered Learning (SCL). Procedia - Social and Behavioral Sciences, 67, 345-348. https://doi.org/10.1016/j.sbspro.2012.11.337.

Martriwati, M., Setyani, R. S., Sari, H. N., \& Kaniadewi, N. (2018). Pelatihan Penggunaan Bahasa Kelas (Classroom Language) Dalam Pembelajaran Bahasa Inggris Bagi Guru SMK Jakarta Pusat 1 Jakarta. Jurnal SOLMA, 7(1), 1. https://doi.org/10.29405/solma.v7i1.645.

Masrur, I., Irawati, E., \& Sulistyo, G. H. (2020). Integrating Writing Process with Quantum Learning Framework in English Language Teaching. Jurnal Pendidikan: Teori, Penelitian, Dan Pengembangan, 5(3). https://doi.org/10.17977/jptpp.v5i3.13262.

Mauliate, H. D., Rahmat, A., \& Wachidah, S. (2019). Evaluation the Lesson Plan of English Language Learning in Junior High School, Seraphine Bakti Utama West Jakarta. International Journal of Scientific Research and Management, 7(07), 1078-1086. https://doi.org/10.18535/ijsrm/v7i7.el02.

Megawati, \& Utami. (2020). English Learning with Powtoon Animation Video. Journal of Education Technology, 4(2), 110. https://doi.org/10.23887/jet.v4i2.25096.

Meşe, E., \& Sevilen, Ç. (2021). Factors influencing EFL students' motivation in online learning: A qualitative case study. Journal of Educational Technology \& Online Learning, 4(1), 11-22. https://doi.org/10.31681/ jetol.817680.

Moghadam, Z. B., Narafshan, M. H., \& Tajadini, M. (2021). Development of a Critical Self in the Language Reading Classroom: An examination of Learners' L2 Self. Thinking Skills and Creativity, 3. https://doi.org/10.1016/j.tsc.2021.100944.

Mohammadi, M., Moenikia, M., \& Zahed-Babelan, A. (2020). The role of advance organizer on English language learning as a second language. Procedia - Social and Behavioral Sciences, 2(2). https://doi.org/10.1016/j.sbspro.2010.03.747.

Nartiningrum, N., \& Nugroho, A. (2020). Online Learning amidst Global Pandemic: EFL Students ' 
Challenges,Suggestions, and Needed Materials. Academic Journal of English Language and Education, 4(2), 115-140. https://doi.org/10.29240/ef.v4i2.1494.

Nishanthi, R. (2018). The Importance of Learning English in Today World. International Journal of Trend in Scientific Research and Development, 3(1), 871-874. https://doi.org/10.31142/ijtsrd19061.

Parvareshbar, F., \& Ghoorchaei, B. (2016). The Effect of Using Short Stories on Vocabulary Learning of Iranian EFL Learners. Theory and Practice in Language Studies, 6(7), 1476. https://doi.org/10.17507/tpls.0607.20.

Putra, R. W. P. (2021). Improving the Students' Motivation in Learning English through Google Meet during the Online Learning. English Learning Innovation, 2(1), 35-42. https://doi.org/10.22219/englie.v2i1.14605.

Ratminingsih, N. M. (2017). Metode dan Strategi Pembelajaran Bahasa Inggris. RajaGrafindo Persada.

Raynesa. (2019). Lesson Planning in EFL Classroom: A Case Study in Lesson Plan Preparation and Implementation. Wiralodra English Journal, 3(2), 367-375. https://doi.org/10.31943/wej.v3i2.67.

Rinekso, A. B., \& Muslim, A. B. (2020). Synchronous online discussion : Teaching English in higher education amidst the covid-19 pandemic. JEES (Journal of English Educators Society), 5(2), 155-162. https://doi.org/10.21070/jees.v5i2.646.

Rokhman, F., \& Yuliati. (2010). The development of the Indonesian teaching material based on multicultural context by using sociolinguistic approach at junior high school. Procedia - Social and Behavioral Sciences, 9(10). https://doi.org/10.1016/j.sbspro.2010.12.353.

Sadegi, M. (2019). A Shift From Classroom to Distance Learning: Advantages and Limitation. International Journal of Research in English Education ( IJREE), 4(1). https://doi.org/10.29252/ijree.4.1.80.

Saito, K., Dewaele, J.-M., Abe, M., \& In'nami, Y. (2018). Motivation, Emotion, Learning Experience, and Second Language Comprehensibility Development in Classroom Settings: A Cross-Sectional and Longitudinal Study. Language Learning, 68(3), 709-743. https://doi.org/10.1111/lang.12297.

Sari, H. I. (2016). Errors In Using English As Classroom Language Committed By The ICT Teacher of SMP Negeri 2 Semarang. EduLite: Journal of English Education, Literature and Culture, I(1), 41-56. https://doi.org/10.30659/e.1.1.41-56.

Selvi, I., Baydilli, N., \& Akinsal, E. C. (2020). Can YouTube English Videos Be Recommended as an Accurate Source for Learning About Testicular Self-examination? Urology, 145. https://doi.org/10.1016/j.urology.2020.06.082.

Sert, N., \& Boynueğri, E. (2017). Digital technology use by the students and English teachers and self-directed language learning. World Journal on Educational Technology: Current Issues, 9(1), 24. https://doi.org/10.18844/wjet.v9i1.993.

Sieberer-Nagler, K. (2015). Effective Classroom-Management \& Positive Teaching. English Language Teaching, 9(1), 163. https://doi.org/10.5539/elt.v9n1p163.

Singh, C. K. S., Singh, T. S. M., Abdullah, N. Y., Moneyam, S., Ismail, M. R., Tek, E., Karupayah, T., Chenderan, K., Singh, M. K. R., \& Singh, J. K. S. (2020). Rethinking English language teaching through Telegram, Whatsapp, Google classroom, and Zoom. Systematic Reviews in Pharmacy, 11(11), 45-54. https://doi.org/10.31838/srp.2020.11.9.

Sujarwo, S. (2020). Students' Perceptions of Using Machine Translation Tools In the EFL Classroom. Al-Lisan, 6(2), 230-241. https://doi.org/10.30603/al.v6i2.1333.

Sujarwo, S., Sukmawati, S., Akhiruddin, A., Ridwan, R., \& Suharti Siradjuddin, S. S. (2020). An Analysis of University Students' Perspective On Online Learning in The Midst of Covid-19 Pandemic. Jurnal Pendidikan Dan Pengajaran, 53(2), 125. https://doi.org/10.23887/jpp.v53i2.24964.

Sulistiyo, U. (2018). Factors Affecting English Language Learning in English as a Foreign Language (EFL) Context: A Literature Review Study. Indonesian Journal Of Educational Research, 3(1), $20-24$. https://doi.org/10.30631/ijer.v3i1.54.

Sya, M. F., \& Helmanto, F. (2020). Pemerataan Pembelajaran Muatan Lokal Bahasa Inggris Sekolah Dasar Indonesia. Jurnal Pendidikan Guru Sekolah Dasar, 7(1). https://doi.org/10.30997/dt.v7i1.2348.

Szőcs, K. (2017). Teachers' and learners' beliefs about language learning autonomy and its implications in the classroom: A mixed method study. Apples - Journal of Applied Language Studies, 11(2), 125-145. https://doi.org/10.17011/apples/urn.201708233542.

Tanihardjo, J. (2016). The Analysis of Students' English Competence in the Grammar Section in the Paper-Based TOEFL: A Case Study at English Department in Bunda Mulia University. Journal of English Language \& Culture, 6(1). https://doi.org/10.30813/jelc.v6i1.270.

Thoyyibah, N., Hartono, R., \& Bharati, D. A. L. (2019). The Implementation of Character Education in the English Teaching Learning Using 2013 Curriculum. English Education Journal, 9(2), 254-266. https://doi.org/10.15294/eej.v9i2.30058.

Tovar Viera, R., Velasco Sánchez, Diego IsmaelTovar Viera, R., \& Velasco Sánchez, D. I. (2020). Research on Technology Competencies in EFL Language Instructors: Technology-Pedagogy-Content in Language 
Teaching. Script Journal: Journal of Linguistics and English Teaching, 5(1), 32-43. https://doi.org/10.24903/sj.v5i1.414.

Tseng, J.-J. (2014). Investigating EFL teachers' technological pedagogical content knowledge: Students' perceptions. CALL Design: Principles and Practice, 2014, 379-384. https://doi.org/10.14705/rpnet.2014.000249.

Tuzlukova, V., Al-Busaidi, S., \& Burns, S. L. (2017). Critical thinking in the language classroom: Teacher beliefs and methods Investigation of the Omani Foundation Program Students' Transitional Challenges: Focus on Computer Self-Efficacy and English Language Proficiency View project Teachers' Efficacy beli.

Wahyudin, A. Y., Jepri, D., Simamora, M. W., Pratiwi, I. W., \& Rina, A. (2020). Penggunaan komik digital toondoo dalam pembelajaran Bahasa inggris tingkat Sekolah menengah. Jurnal of Social and Tevhnologi for Community Service, 1(1), 1-6. https://doi.org/10.33365/jta.v1i1.673.

Whitehead, S. J. (2021). “I thought we weren’t in Spain!”: Discursive negotiations of realness in a foreign language classroom. System, 100. https://doi.org/10.1016/j.system.2021.102532.

Wichadee, S. (2011). Developing The Self-Directed Learning Instructional Model To Enhance English Reading Ability And Self-Directed Learning Of Undergraduate Students. Journal of College Teaching \& Learning (TLC), 8(12), 43. https://doi.org/10.19030/tlc.v8i12.6620.

Widyahening, E. T. (2018). Penggunaan Classroom Language Dalam Pembelajaran Bahasa Inggris Bagi Guru Sdn 01 Suruh Tasikmadu Karanganyar. ADIWIDYA, $\quad$ II(2), $159-166$. https://doi.org/10.33061/awpm.v2i2.2518.

Wilt, F. Van Der, Bouwer, R., \& Veen, C. Van Der. (2021). Dialogic classroom talk in early childhood education : The effect on language skills and social competence. Learning and Instruction, July, 101522. https://doi.org/10.1016/j.learninstruc.2021.101522.

Yafaei, Y. Al, \& Attamimi, R. (2019). Understanding Teachers' Integration of Moodle in EFL Classrooms: A Case Study. English Language Teaching, 12(4). https://doi.org/10.5539/elt.v12n4p1.

Yang, Q., Bartholomew, C. P., Ansari, A., \& Purtell, K. M. (2022). Classroom age composition and preschoolers' language and literacy gains: The role of classroom engagement. Early Childhood Research Quarterly, 60. https://doi.org/10.1016/j.ecresq.2022.01.001.

York, J. (2011). Reasons for using YouTube in the language classroom include practical usage examples. Jaltcalljournal, 7(2), 207-215.

Yunita, W., \& Maisarah, I. (2020). Students ' Perception On Learning Language At The Graduate Program OF English Education Amids The Covid 19 Pandemic. Linguists: Journal of Linguistics and Language Teaching, 2069(6), 107-120. https://doi.org/10.29300/ling.v6i2.3718.

Yusnidar. (2014). Penerapan Metode Gallery Walk Untuk Meningkatkan Kemampuan Menulis Teks Analytical Exposition Bahasa Inggris Siswa Kelas XI Ipa-1 Man Model Banda Aceh. Getsempena English Education Journal, 1(2). https://doi.org/10.46244/geej.v1i2.676.

Zarei, A. A., \& Afshar, N. S. (2014). Multiple Intelligences As Predictors Of Reading Comprehension And Vocabulary Knowledge. Indonesian Journal Of Applied Linguistics, 4(1). https://doi.org/10.17509/ijal.v4i1.598. 